\title{
TEKNIK PENERJEMAHAN ABSTRAK SPectā DALAM JURNAL FOTOGRAFI
}

Journal of Photography

Arts, and Media
Febriansyah Ignas Pradana

Sekolah Tinggi Teknologi Kedirgantaraan

(STTKD) Yogyakarta

Surel: ignaspradana@gmail.com

Volume 3 Nomor 1 ,

Mei 2019: 39-49

\begin{abstract}
Abstrak
Pada hakikatnya ketika seseorang menerjemahkan sebuah pesan dari bahasa sumber ke bahasa sasaran maka ia telah menjadi seorang penerjemah. Teknik penerjemahan digunakan oleh penerjemah, baik lisan dan tulis, untuk memindahkan sebuah pesan dari bahasa sumber ke bahasa sasaran. Pemilihan teknik penerjemahan berpengaruh terhadap keberhasilan penyampaian pesan dan gagasan. Penelitian ini mendeskripsikan (1) teknik penerjemahan yang digunakan oleh penulis dalam penulisan abstrak berbahasa Inggris dalam sebuah jurnal fotografi, dan (2) persentase teknik penerjemahan yang paling dominan digunakan. Data dalam penelitian ini adalah kalimat-kalimat dalam abstrak berbahasa Inggris yang diterjemahkan dari abstrak berbahasa Indonesia. Data diperoleh dari jurnal fotografi nasional yaitu Jurnal Specta volume 2 no. 2 yang diterbitkan pada tahun 2018. Data dianalisis berdasarkan teori teknik penerjemahan yang dikemukakan Molina dan Albir. Hasil menunjukkan bahwa penulis paling dominan menggunakan teknik penerjemahan literal dalam menerjemahkan abstrak berbahasa Inggris dalam jurnal fotografi. Hasil dari penelitian ini sangat erat dengan ideologi penerjemahan yang digunakan oleh penerjemah.
\end{abstract}

Kata kunci: teknik penerjemahan, jurnal fotografi, ideologi, spectā, penerjemahan

\begin{abstract}
Translation Technique for Abstract in a Photography Journal. Fundamentally, we are all becaming translators when we are translating messages from source language into target language. The translation techniques are used by the translators, either in spoken or written translation, in transferring messages from source language to target language. Translation techniques play such an important role toward the success of transferring idea and thought from one language to other language. This study aims to describe (1) which translation techniques, and (2) the percentage of the translation techniques used by authors in English abstract of photography journal. Data on this study are sentences which is translated from Bahasa into English. We collected the data from national photography journal, namely Specta volume 2 no. 2 which was published in 2018. Furthermore, we analyzed the data based on the translation techniques theory conducted by Molina and Albir. The result shows that the authors dominantly used literal techniques to translate the abstracts. Thus, from the result we are able to perceive the translation ideology of the translators.
\end{abstract}

Keywords: translation techniques, translation, photography journal, spectā, ideology 


\section{PENDAHULUAN}

Untuk dapat berkomunikasi secara efektif, baik melalui lisan maupun tulisan, seseorang perlu memiliki kemampuan retorikal yang baik (Hendrikus, 2011). Dalam konteks akademik, kemampuan retorikal tersebut diwujudkan melalui penulisan artikel ilmiah (Hyland, 2008). Artikel-artikel ilmiah yang telah disusun oleh para akademisi dapat dipublikasikan melalui jurnal-jurnal dan prosiding ilmiah. Penulisan artikel ilmiah yang tidak terbatas ditulis dalam bahasa Indonesia mewajibkan para akademisi untuk dapat memiliki pemahaman yang baik dalam memahami bahasa kedua selain bahasa Indonesia, khususnya bahasa Inggris. Bahasa Inggris memegang peranan penting dalam segala kegiatan akademis (Kirkpatrick dan Sussex, 2012).

Dalam proses memahami segala pesan dan gagasan yang terdapat dalam artikel-artikel berbahasa Inggris, setiap individu tentu mengalami sebuah proses penerjemahan. Proses penerjemahan menjadi sebuah proses yang penting dalam pemindahan pesan dan gagasan dari suatu bahasa ke bahasa lain. Dewasa ini, proses tersebut sangat erat dengan segala aktivitas, baik dalam bidang akademik dan praktis. Hakikatnya, setiap individu adalah seorang penerjemah ketika memindahkan sebuah pesan dari bahasa sumber ke bahasa sasaran. Secara gamblang, Nida dan Taber (Nida \& Taber, 1982) menyatakan bahwa terjemahan merupakan pembuatan atau penciptaan ulang pesan dari bahasa sumber dengan padanan natural terdekat di bahasa sasaran. Senada, Catford menyatakan bahwa masalah inti dari penerjemahan adalah menemukan kesepadanan terjemahan pada bahasa sasaran (Catford, 1965). Menanggapi masalah tersebut, Molina dan Albir (Molina \& A.H, 2002) menjelaskan 18 teknik penerjemahan yang bisa digunakan oleh penerjemah untuk memindahkan pesan, baik tertulis atau tertutur, dari bahasa sumber ke bahasa sasaran.

Teknik penerjemahan tersebut antara lain (1) adaptasi, (2) amplifikasi, (3) peminjaman, (4) kalke, (5) kompensasi, (6) deskripsi, (7) kreasi diskursif, (8) padanan lazim, (9) generalisasi, (10) amplifikasi linguistik, (11) kompresi linguistik, (12) harfiah, (13) modulasi, (14) partikularisasi, (15) reduksi, (16) substitusi, variasi, (18) transposisi. Teknik-teknik penerjemahan tersebut dapat digunakan oleh penerjemah sebagai strategi dalam proses penerjemahan.

Dalam sebuah artikel atau penulisan ilmiah terdapat sebuah bagian yaitu abstrak, yang berisi penyajian singkat mengenai isi atau intisari dari sebuah artikel ilmiah (Noor, 2016). Untuk membuat sebuah artikel ilmiah lebih mudah diakses dan dipahami oleh pembaca, abstrak tersebut ditulis dalam bahasa Indonesia dan diterjemahkan ke dalam bahasa Inggris. Penelitian ini membahas mengenai (1) teknik penerjemahan yang digunakan oleh penulis dalam penulisan abstrak berbahasa Inggris dalam sebuah jurnal, dan (2) persentase teknik penerjemahan yang paling dominan digunakan.

Data dalam penelitian ini adalah kalimat-kalimat dalam abstrak berbahasa Inggris yang diterjemahkan dari abstrak berbahasa Indonesia. Data diperoleh dari jurnal fotografi nasional yaitu Jurnal Specta volume 2 no. 2 yang diterbitkan pada tahun 2018. Data dianalisis berdasarkan teori teknik penerjemahan yang dikemukakan Molina dan Albir (Molina \& A.H, 2002). 


\section{PEMBAHASAN}

Dalam penelitian ini berhasil ditemukan 32 data berupa kalimat bahasa sumber yang diterjemahkan oleh seorang penerjemah ke dalam bahasa sasaran. Dari keseluruhan data tersebut, teknik penerjemahan yang paling banyak digunakan adalah teknik literal. Lebih lanjut, berikut adalah diagram persentase dari penggunaan teknik penerjemahan oleh penerjemah.

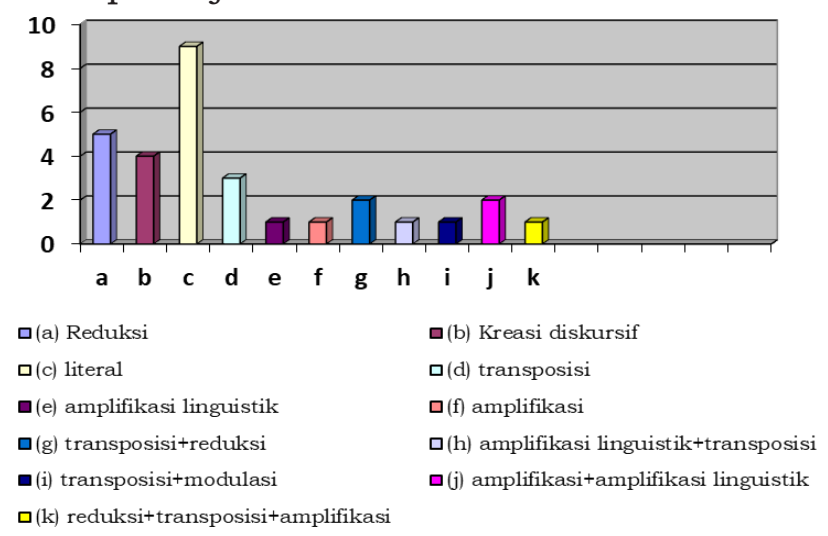

Diagram1. Penerapan Teknik Penerjemahan

\section{A. Teknik Tunggal}

\section{A.1 Teknik Reduksi}

Sehubungan dengan tujuan dari penerjemah untuk mempersingkat dan meringkas pesan, penerjemah terkadang dikondisikan untuk mengurangi beberapa elemen dari kalimat sumber, terutama pada kalimat komplek atau majemuk. Teknik pengurangan tesebut disebut teknik reduksi. Dalam penelitian ini teknik reduksi dijumpai dalam lima data. Lebih lanjut, penggunaan teknik ini dapat dilihat pada data berikut.

(1) BSu: Metodeyangdigunakan yakni observasi dan wawancara. Kegiatan analisis data dimulai dari tahap pengumpulan data, tahap reduksi, tahap penyajian data, serta tahap penarikan kesimpulan dengan penelitian kualitatif.
BSa: The method used is observation and interview. Data analysis activities started from the data collection stage, the reduction phase, the data presentation stage, and the conclusion with qualitative research. (D16)

(2) BSu: Berdasarkan hal ini munculgagasan untukmencocokkan aroma parfum dengan beberapa kepribadian lalu merepresentasikan aroma parfum tersebut melalui media fotografi.

BSa: Based on this came the idea to match the scent of perfume with some personality and then represent the fragrance of the perfume through the photography. (D21)

(3)

BSu: Karya tugas akhir fotografi ini diharapakan dapat membantu konsumen menginterpretasikan aroma parfum secara visual agar lebih mudah memilih produk parfum yang disukai sesuai dengan kepribadian yang dimiliki.

BSa: This photography work is expected to help consumers interpret the perfume scent visually to help them choose the preferred perfume product in accordance with their personality. (D24)

(4) BSu: Metode penelitian yang digunakan untuk menganalisis adalah metode kualitatif yang menganggap bahwa setiap petunjuk adalah penting untuk dianalisis.

BSa: $\quad$ The method employed in this research was qualitative method which considered that each clue was important to be analyzed (D4) 
Pada contoh (1) penerjemah melesapkan satuan-satuan kebahasaan atau informasi tertentu, yaitu kata-kata atau kalimat yang dicetak tebal pada contoh (1) yaitu kata 'penarikan' pada frasa verba 'penarikan kesimpulan'. Pengurangan muatan informasi ini dipengaruhi oleh beberapa faktor. Dalam bahasa Inggris, kata conclusion 'kesimpulan' berkolokasi dengan verba draw 'menggambar' menjadi draw conclusion untuk menyatakan 'penarikan kesimpulan'.

Selanjutnya, pada contoh (2) penerjemah melesapkan kata 'media' pada frasa nomina 'media fotografi', dan pada contoh (3) frasa nomina 'tugas akhir' dilesapkan dalam penyampaiannya di bahasa sasaran. Pelesapan-pelesapan tersebut dipengaruhi oleh beberapa faktor, baik teknis dan non-teknis (Pradana, 2019).

\section{A.2 Teknik Kreasi Diskursif}

Kreasi diskursif adalah teknik penerjemahan yang menghasilkan terjemahan di luar konteks atau teknik yang dimaksudkan untuk menampilkan kesepadanan sementara yang tidak terduga atau keluar dari konteks. Teknik ini lazim diterapkan dalam menerjemahkan judul buku atau judul film. Contoh pada judul buku Rumble Fish diterjemahkan sebagai 'hukum jalanan'. Terdapat 4 buah data yang menggunakan teknik penerjemahan kreasi diskursif ini. Penggunaan teknik ini dituangkan sebagai berikut.

(5)

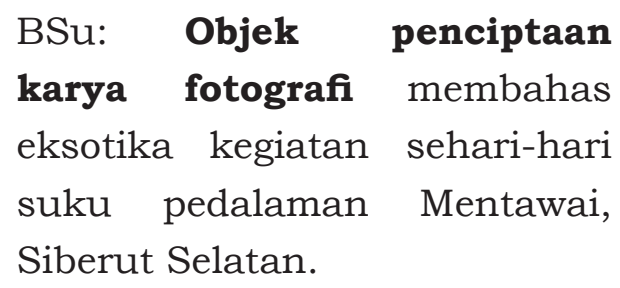

BSa: This abstract discusses the daily exotica of object creation in the heart of Mentawai, South Siberut. (D8)

(6)

\section{BSu: Penciptaan karya}

fotografi ini berorientasi dengan eksotika kegiatan sehari-hari suku Mentawai sebagai dasar acuan proses penciptaan dengan metode observasi,eksplorasi, pemotretan. Karya foto dibuat dalam fotografi dokumenter, dengan mengambil peristiwaperistiwa yang menarik lewat bidang jurnalistik.

BSa: This abstract is oriented in Mentawai tribe as a basis creation process using observation, exploration, and experimental methods. The photographs are made with documentary photography that captures enticing events through journalism. (D12)

Dapat dicermati pada korpus data (5) dan (6) penerjemah menerapkan teknik penerjemahan kreasi diskursif yaitu dengan diterjemahkannya kata hingga klausa yang dicetak tebal. Pada data (5) dapat dicermati pesan bahasa sumber yaitu 'objek penciptaan karya fotografi' diterjemahkan menjadi this abstract 'abstrak ini'. Terlihat hasil terjemahan yang tidak terduga dari penerjemah. Selanjutnya, pada data (6), pun dipahami terdapat hasil terjemahan yang keluar dari konteks yang ditandai dengan diterjemahkannya 'penciptaan karya fotografi' menjadi abstract 'abstrak'.

\section{A.3 Teknik Transposisi}

Teknik penerjemahan transposisi adalah teknik penerjemahan dimana penerjemah melakukan perubahan kategori 
gramatikal. Teknik ini sama dengan teknik pergeseran kategori, struktur dan unit. Seperti kata menjadi frasa. Terdapat 3 buah data yang menggunakan teknik penerjemahan transposisi ini. Penggunaan teknik ini dituangkan sebagai berikut.

$$
\begin{aligned}
& \text { BSu: Penciptaan } r \text { karya } \\
& \text { didasari oleh minimnya } \\
& \text { informasi tentang } \\
& \text { masyarakat pedalaman dusun } \\
& \text { Buttui dan diciptakan karya ini, } \\
& \text { diharapkan mampu memberi } \\
& \text { gambaran dan informasi } \\
& \text { tentang kehidupan para suku } \\
& \text { pedalaman di Mentawai melalui } \\
& \text { fotografi dokumenter. }
\end{aligned}
$$

BSa: This work, with a lack of source information, is based on the daily lives of rural people in Buttui village. It is created with the hopes of capturing and giving information about the tribe lives in rural Mentawai through documentary photography. (D11)

Dapat dicermati pada korpus data (7) penerjemah menerapkan teknik penerjemahan transposisi yaitu dengan diterjemahkannya frasa pada bahasa sumber menjadi kata pada bahasa sasaran yang pada contoh data dicetak tebal. Pada data (7) dapat dicermati pesan bahasa sumber yaitu 'memberi gambaran' diterjemahkan menjadi capturing 'menangkap'.

\section{A.4 Teknik Amplifikasi Linguistik}

Teknik ini diaplikasikan dengan menambah elemen-elemen linguistik. Teknik ini lazim diterapkan dalam kejurubahasaan secara konsekutif atau dalam sulih suara (dubbing). Terdapat 1 data dalam penulisan yang memperlihatkan penggunaan teknik ini oleh seorang penerjemah. Penggunaan teknik penerjemahan ini dapat dilihat pada data berikut. BSu: Dalam upaya mewujudkan foto potret yang sesuai dengan fungsi-fungsi tersebut, pengunjung tampak memperhitungkan aspek teknis-fisik fotografi potret berupa pencahayaan, pose, dan background.

BSa: In order to make her/ his portrait matches on the function desired, visitor seems to care about physical-technical aspects on portrait photography: lighting, pose, and background. (D6)

Dapat dicermati pada korpus data (8) penerjemah menerapkan teknik penerjemahan amplifikasi linguistik yaitu dengan ditambahkannya pronomina persona atau personal pronoun yaitu her/ his 'dia (perempuan) / dia (laki-laki)'. Peneliti berasumsi bahwa teknik penerjemahan tersebut didasari oleh keinginan penulis untuk memperjelas pesan pada bahasa sasaran.

\section{A.5 Teknik Amplifikasi}

Tidak jauh berbeda dengan teknik penerjemahan sebelumnya, teknik penerjemahan ini diaplikasikan dengan menambah informasi atau penjelasan mengenai isi pesan bahasa sumber. Terdapat 1 data dalam penulisan yang memperlihatkan penggunaan teknik ini oleh seorang penerjemah. Penggunaan teknik penerjemahan ini dapat dilihat pada data berikut.

BSu: Adapun poperti, kurang mendapatkan perhatian dikarenakan tidak semua anjungan menyediakannya.

BSa: Another element is property, 
which is the most ignorable element due to it's rare availability on the spot. (D6)

Dapat dicermati pada korpus data (9) penerjemah menerapkan teknik penerjemahan amplifikasi yaitu dengan memberi penjelasan tambahan pada hasil terjemahan bahasa sasaran yaitu frasa another element 'elemen lain' dan klausa relatif which is the most ignorable element '(yang) merupakan elemen yang diabaikan'. Dapat dicermati frasa dan klausa pada bahasa sasaran tidak dijumpai pada bahasa sumber. Teknik penerjemahan amplifikasi tersebut bertujuan untuk memberikan penjelasan tambahan yang dapat memudahkan pembaca bahasa sasaran. Penggunaan teknik penerjemahan amplifikasi lazim ditemui pada istilah-istilah yang kurang lazim di bahasa sasaran. Teknik penerjemahan ini memiliki kemiripan dengan teknik penerjemahan deskripsi. Perbedaan kedua teknik penerjemahan tersebut terletak pada penghilangan istilah asli bahasa sumber.

\section{A.6 Teknik Penerjemahan Literal}

Teknik penerjemahan ini dijelaskan sebagai terjemahan yang mengutamakan padanan kata atau ekspresi di dalam bahasa sasaran yang mempunyai rujukan atau makna yang sama dengan kata atau ekspresi dalam bahasa sumber. Dalam penulisan ini, penggunaan teknik literal dapat dijumpai dalam 9 data. Penggunaan teknik ini dapat dilihat pada data berikut.

(10)

BSu: Terdapat banyak merek parfum yang beredar di pasaran.

BSa: There are many brands of perfume circulating in the market. (D26)

BSu: Hal tersebut tentu mempersulit konsumen untuk menentukan aroma yang cocok dengan keinginan dan kepribadiannya, karena pada umumnya konsumen tidak mengenal jenis bebauan yang menjadi bahan pembuatan parfum secara spesifik.

BSa: it certainly makes it difficult for consumers to determine the scent that matches the desires and personality because consumers generally do not recognize the type of smell that became the ingredient of perfume making specificly. (D28)

$\mathrm{BSu}$ Informasi tentang produk parfum yang telah dikumpulkan melalui observasi akan ditampilkan secara visual fotografi dengan menggunakan objek pendukung yang memiliki interpretasi secara metafora sedekat mungkin dengan aroma, bentuk botol kemasan, tujuan, dan inspirasi pembuatan parfum, atau kepribadian dalam color rosette test.

BSa: Information about perfume products that have been collected through observation will be visually displayed photographically by using a support object that has metaphorically interpreted as close as possible to the fragrance, the shape of the packaging bottle, the purpose and inspiration of the perfume making, or the personality in the color rosette test. (D29) 
BSu: Karya fotografi yang diciptakan merupakan karya fotografi produk yang pemotretannya dilakukan di dalam ruangan dengan menggunakan sumber pencahayaan berupa lampu flash dengan tambahan peralatan penunjang berupa softbox, lightbox, blackglass, dan color gel.

BSa: The work of photography created is the work of product photography that shoot indoors by using the flash lights as the light source with additional supporting equipment such as softbox, lightbox, blackglass, and color gel. (D31)

(14)

BSu: Teknik fotografi yang diterapkan pada proses penciptaan karya meliputi teknik pencahayaan seperti hi-key dan low-key disertai penggunaan teknik high speed pada beberapa karya yang menggunakan objek pendukung yang bergerak.

BSa: Photography techniques applied to the process of creating works are photography lighting techniques such as hi-key and low-key and by the use of high speed techniques on some works that use moving support objects. (D32)

(15)

BSu: Penelitian ini hendak mengkaji fungsi-fungsi dokumenter dalam karya fotografi yang divisualisasikan berdampingan dengan gambargambar komik dalam sebuah novel grafis berjudul 'The Photographer: Into War-Torn Afghanistan with Doctors without Borders'.

BSa: This research studied the documentary function in photography works visualized side to side with the comic drawings in a graphic novel titled 'The Photographer: Into WarTorn Afghanistan with Doctors without Borders'. (D9)

(16) BSu: Tujuan dari penelitian ini adalah untuk mencari tahu apakah nilai dokumenter karya foto bisa tetap diapresiasi layaknya foto dokumenter ataukah ada peralihan fungsi ketika dua jenis piktorial disandingkan bersamaan.

BSa: The aim of this research was to find out whether the documentary photographs are still appreciated as they are, or there are any changes of function when those two pictorials are juxtaposed. (D17)

Dapatdicermatipadakorpus data(10) hingga data (16) penerjemah menerapkan teknik penerjemahan literal yaitu teknik penerjemahan yang menjaga keutuhan dan susunan pesan bahasa sumber ke bahasa sasaran. Teknik penerjemahan ini adalah teknik penerjemahan yang lazim digunakan oleh penerjemah baik lisan ataupun tulis. Teknik penerjemahan literal tersebut dipengaruhi oleh rendahnya tingkat interferensi antara dua bahasa.

B. Teknik Penerjemahan Couplet

\section{B.1 Teknik Transposisi+Reduksi}

Dalam sebuah proses penerjemahan, 
penerjemah dapat menggunakan lebih dari satu teknik penerjemahan. Penggabungan dua teknik penerjemahan disebut dengan teknik penerjemahan couplet. Penyebutan tersebut juga berlaku untuk tiga penggunaan teknik penerjemahan (triplet), empat teknik penerjemahan (quadruplet), dan lima teknik penerjemahan (quintuplet). Berikut adalah korpus data yang menunjukkan penggunaan teknik penerjemahan couplet oleh penerjemah.

BSu: Penelitian ini membahas permasalahan tentang monitoring urban farming yang dilakukan oleh anak dengan menggunakan media pembelajaran fotografi sebagai pendokumentasian lingkungan tempat tinggal anak di wilayah pegirian Surabaya.

BSa: This study discusses the problem of urban farming monitoring conducted by children by using photography learning media as a documentation of the environment where children live in the Surabaya area. The issues addressed discuss how the role of photography media is used as urban farming monitoring in Surabaya area and the impact of family and child monitoring with the participation of children in creating child friendly environment in Surabaya area. (D1)

Pada korpus data (17) penerjemah menerapkan teknik penerjemahan transposisi serta reduksi secara bersamaan. Pengertian dari kedua teknik penerjemahan tersebut telah dicantumkan dalam subbab sebelumnya. Faktor penggunaan teknik penerjemahan tersebut dipengaruhi oleh interferensi bahasa sumber dan bahasa sasaran yang relatif tinggi.

\section{B.2 Teknik Amplifikasi \\ Linguistik+Transposisi}

Dalam penelitian ini berhasil ditemukan satu data yang menunjukkan penggunaan teknik penerjemahan amplifikasi linguistik dan transposisi dalam satu korpus data. Berikut adalah korpus data yang menunjukkan penggunaan teknik penerjemahan couplet tersebut.

(18)

BSu: Dapat disimpulkan bahwa hasil dari monitoring urban farming berbasis pendokumentasian dan partisipasi anak dalam menciptakan lingkungan ramah anak di wilayah Pegirian Surabaya dengan menggunakan media fotografi dapat dijadikan sebagai acuan untuk mendokumentasikan perubahan lingkungan yang terjadi, fotografi dapat digunakan sebagai alat agar anak dan masyarakat bisa berpartisipasi dalam kegiatan lingkungan ramah anak, dan dampaknya bagi keluarga yang diberikan tanaman urban farming mengalami perubahan perilaku menjadi lebih baik dalam merawat tanaman dan menjaga lingkungan serta hubungan antar anggota keluarga dan antar warga menjadi lebih erat.

BSa: This study discusses the problem of urban farming monitoring conducted 
by children by using photography learning media as a documentation of the environment where children live in the Surabaya area. The issues addressed discuss how the role of photography media is used as urban farming monitoring in Surabaya area and the impact of family and child monitoring with the participation of children in creating child friendly environment in Surabaya area.

Pada korpus data (18) penerjemah menerapkan teknik penerjemahan amplifikasi linguistik dan transposisi secara bersamaan. Penerapan penggunaan kedua teknik penerjemahan tersebut dapat dilihat pada tataran kata dan klausa yang dicetak tebal. Teknik penerjemahan amplifikasi linguistik ditunjukkan dengan berubahnya kategori pesan dalam bahasa sumber yaitu 'anak' menjadi 'anak-anak' dalam bahasa sasaran.

\section{B.3 Teknik Transposisi+Modulasi}

Dalam penelitian ini berhasil ditemukan satu data yang menunjukkan penggunaan teknik penerjemahan transposisi dan modulasi dalam satu korpus data. Teknik penerjemahan modulasi adalah teknik penerjemahan yang menggunakan perubahan sudut pandang. Berikut adalah korpus data yang menunjukkan penggunaan teknik penerjemahan couplet tersebut.

BSu: Suatu cara pandang baru dan inspiratif bagi yang melihat dan merasakan dapat membuka mata kita seutuhnya tentang lingkungan budaya di sekitar kita yang mulai terkikis oleh kerasnya kemajuan dan ketatnya perkembangan zaman.

BSa: A new perspective and inspiration will completely open people's eyes, for those who see and feel, on the nowadays cultural environment which slowly eroded by the rough progress and tight developmental era. (D5)

Pada korpus data (19) teknik penerjemahan modulasi ditandai dengan berubahnya sudut pandang dari bahasa sumber berupa pronomina persona 'kita' menjadi people 'orang' pada bahasa sasaran. Teknik selanjutnya yang digunakan adalah teknik penerjemahan transposisi yang ditunjukkan dengan berubahnya kata sifat atau adjektiva 'inspiratif' pada bahasa sumber menjadi nomina atau kata benda yaitu inspiration 'inspirasi' pada bahasa sasaran.

\section{B.4 Teknik Amplifikasi Linguistik+Amplifikasi}

Kedua teknik penerjemahan ini memang rumit untuk dibedakan. Perbedaan mendasar terletak pada tataran dan tingkat informasi yang ditambahkan pada bahasa sasaran. Berikut adalah korpus data yang menunjukkan penerapan kedua teknik penerjemahan yang berhasil ditemukan pada penelitian ini

BSu: Menerapkan metode penelitian deskriptif-kualitatif, analisis kritis dilakukan dalam pembacaan foto-foto potret menggunakan telaah fungsi foto potret Soeprapto Soedjono, serta telaah 
aspek teknis-fisik fotografi potret yang dikemukakan oleh Famous Photographers School.

BSa:

This research allows the descriptive-qualitative method. It uses the study of the portrait functions explained by Soeprapto Soedjono to read and to analise the portrait photos. It also studies the physicaltechnical aspect in portrait photography explained by Famous Photographers School applied by the visitors. (D15)

Pada korpus data (20) dapat dipahami teknik penerjemahan amplifikasi terlihat pada penambahan penjelasan yang terdapat pada bahasa sasaran yaitu frasa this research 'penelitian ini' untuk menjelaskan klausa 'menerapkan metode penelitian deskriptif-kualitatif...'. Senada, penjelasan di akhir korpus data berupa klausa applied by the visitors 'diterapkan oleh pengunjung' yang ditambahkan untuk menjelaskan informasi dari bahasa sumber. Selanjutnya, teknik penerjemahan amplifikasi linguistic terlihat dengan penambahan pronomina it 'itu' pada bahasa sasaran yang tidak terdapat pada pesan sumber.

\section{Teknik Penerjemahan Triplet Teknik Penerjemahan \\ Reduksi+Transposisi+Amplifikasi}

.Seperti telah dijelaskan sebelumnya penerapan teknik penerjemahan dapat menggunakan hingga tiga teknik penerjemahan sekaligus atau disebut triplet. Dalam penelitian ini berhasil ditemukan 1 data yang menunjukkan penggunaan teknik penerjemahan triplet. bermaksud menjelaskan orientasi fotografi pengunjung yang berfoto di anjungan wisata kawasan Mangunan dengan objek penelitian berupa foto potret di media sosial Instagram.

BSa: This research explains the photography orientation of visitors who taking photograph of theirselves (portrait) on the scenary stages (selfie spots) in Mangunan tourism area, by studying their portraits in social media Instagram. (D22)

Penerapan teknik reduksi dapat dicermati pada penghilangan verba 'bermaksud' pada bahasa sasaran. Selanjutnya, teknik penerjemahan transposisi ditunjukkan dengan berubahnya nomina 'pengunjung' yang berjenis tunggal atau singular pada bahasa sumber menjadi visitors 'para pengunjung' pada bahasa sasaran. Teknik penerjemahan terakhir yang digunakan dalam menerjemahkan pesan dalam bahasa sumber ke bahasa sasaran pada korpus data di atas adalah teknik penerjemahan amplifikasi yang ditandai dengan ditambahkannya kata theirselves 'mereka' pada pesan bahasa sasaran.

\section{SIMPULAN}

Berdasarkan hasil dan pembahasan dari penelitian ini maka dapat dipahami bahwa (1) teknik penerjemahan yang digunakan oleh penerjemah dapat menjadi strategi dalam memindahkan pesan dan gagasan dari bahasa sumber ke bahasa sasaran, (2) teknik-teknik penerjemahan yang digunakan oleh penerjemah tidak membatasi hasil terjemahan dalam bahasa sasaran, dan (3) teknik penerjemahan yang dominan digunakan dalam jurnal fotografi 
adalah teknik penerjemahan literal, yang berarti penerjemah sanghat menjaga keutuhan, susunan dan struktur pesan bahasa sumber ke bahasa sasaran.

Penelitian ini memiliki keterbatasan pada sumber data yang digunakan. Diharapkan pada peneliti selanjutnya untuk dapat melanjutkan penelitian ini dengan sumber data yang memiliki kuantitas lebih tinggi. Dengan banyaknya sumber data yang digunakan diharapkan hasil dari penelitian ini yang menunjukkan bahwa teknik penerjemahan yang dominan digunakan dalam jurnal fotografi adalah teknik penerjemahan literal menjadi lebih representatif.

\section{KEPUSTAKAAN}

Catford, J. C. (1965). A Linguistic theory of translation. London: Oxford Press.

Hendrikus. (2011). Retorika. Yogyakarta: Kanisius.

Hyland. (2008). Hedging in academic purposes. English for Specific Purposes, 13(3), 239-256.

Molina, L., \& A.H, A. (2002). Translation techniques revisited: a dynamic and functionalist approach. Meta Translator Journals, 47(4).

Nida, \& Taber. (1982). The theory and practice of translation. Leiden: E.J Brill.

Noor, J. (2016). Metodologi penelitian: skripsi, tesis, disertasi dan karya ilmiah. Jakarta: Kencana.

Pradana, F. I. (2019). Teknik penerjemahan dalam kejurubahasaan konsekutif. Yogyakarta: Pascasarjana Universitas Gadjah Mada. 